\title{
OPERATION UNDER HYPOTHERMIA IN A PREGNANT WOMAN WITH AN INTRACRANIAL ARTERIOVENOUS MALFORMATION
}

\author{
Akitomo MatsuKi, M.D. ${ }^{*}$ and TsUtomu Oyama, M.D. $\dagger$
}

Surgical tREATMENT dURING PhegNanCY was formerly viewed as drastic, but it has been undertaken safely without prohibitive foetal and maternal mortality. In contrast to the many reported intracranial operations under hypothermia, only nineteen such operations have been reported in pregnant women. We wish to present one further case to demonstrate the safety and effectiveness of hypothermia during intracranial surgical interventions in the pregnant woman. This then is the twentieth such case under hypothermia, and only the fifth where the lesion was a cerebral arteriovenous malformation.

\section{Case Rerort}

The patient, aged 26 , was a para 1 , four-month pregnant woman who, with the exception of a previous episode of unconsciousness, had enjoyed excellent health until noon on November 23rd, 1969, when she had a sudden attack of severe headache, followed by loss of consciousness. This was accompanied by frequent vomiting and slight elevation of body temperature to $37.5^{\circ} \mathrm{c}$ axillary. She was brought immediately to the outpatient clinic of the Division of Internal Medicine, Aomori Prefectural Hospital. The next day she regained consciousness but complained of severe pain in the right frontal and occipital regions. The spinal fluid obtained by lumbar puncture was bloody. Following 24 hours bed rest, the headache subsided gradually and she could take food orally. Thereafter she was transferred to the Division of Neurosurgery.

The previous episode of unconsciousness had occurred in 1957 and had lasted for three days. It had been treated as cerebral bleeding in the Division of Paediatrics, Aomori Prefectural Hospital. In 1967 she went through an uncomplicated pregnancy and delivery. The family history was not contributory.

On admission to the Neurosurgical Division, the blood pressure was $130 / 70 \mathrm{~mm}$ $\mathrm{Hg}$, pulse rate 87 beats per minute, temperature $37.0^{\circ} \mathrm{C}$ and respirations 13 per minute. The breasts were slightly enlarged. The size of the uterus, confirmed by pelvic examination, was compatible with an intrauterine gestation of four months' duration. The pupils were both fully reactive to light. Bilateral carotid angiograms, obtained on November 28,1969 , showed a large arteriovenous anomaly in the right frontotemporal lobe. The ECG was within normal limits. The haemoglobin was 7.9 gms. per $100 \mathrm{ml}$, RBC $382 \times 10^{4}$ per cubic mm, haematocrit 41 per cent, bleeding time $6 \mathrm{~min}$, clotting time $7.5 \mathrm{~min}$ and prothrombin time $14.1 \mathrm{sec}$. Blood

\footnotetext{
-Research Fellow, Department of Anesthesiology, Hirosaki University School of Medicine, Aomori-Ken, Japarı.

†Professor and Chairman, Department of Anesthesiology, Hirosaki University Sehool of Medicine, Aomori-Ken, Japan.
} 


\section{Anesthesla Record M.s. 26y. Female}

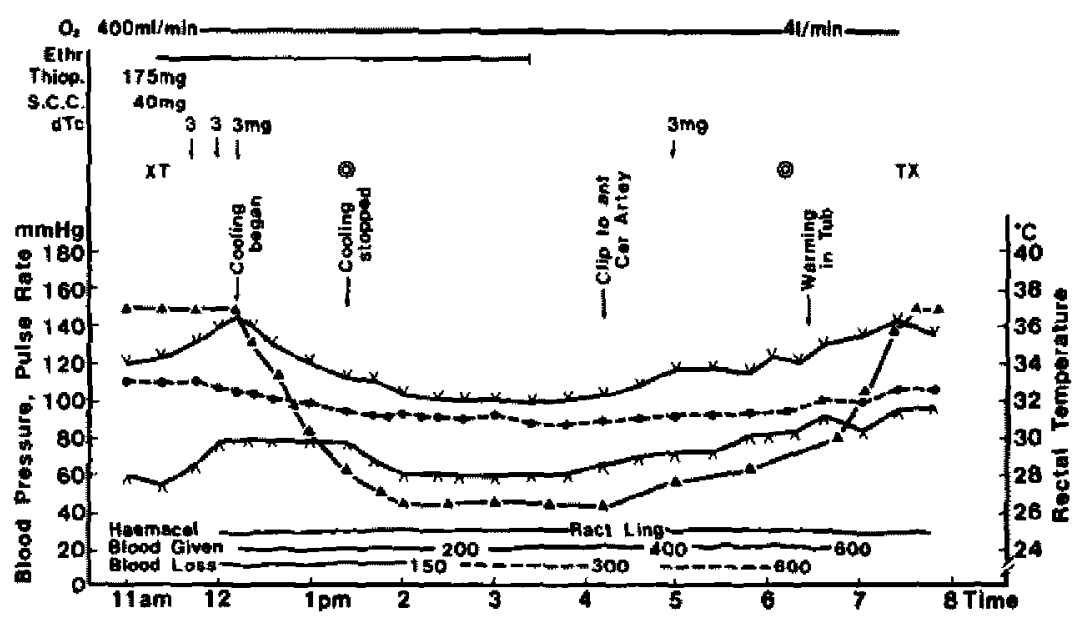

Fuguae 1

chemistry did not reveal any disturbances in liver and kidney functions. Serum electrolytes were: sodium $133.4 \mathrm{mEq}$ per liter, potassium $4.2 \mathrm{mEq}$ per liter, chloride $99.5 \mathrm{mEq}$ per liter. Urinalysis also was normal.

On December 9,1969 , that is sixteen days after the original episode, a craniotomy under hypothermia was performed. "Lutes depot" containing $10 \mathrm{mg}$ of oestradiol benzoate and $125 \mathrm{mg}$ of hydroxyprogesterone caproate was adrinistered intramuscularly the preceding night. Premedication was with $50 \mathrm{mg}$ of hydroxydione and $0.5 \mathrm{mg}$ of atropine sulfate intramuscularly 1 hour before induction of anaesthesia, which was accomplished with $175 \mathrm{mg}$ of thiopentone followed by endotracheal intubation under relaxation produced by $40 \mathrm{mg}$ of intravenous succinylcholine. Anaesthesia was maintained with ether-oxygen in a closed circuit with carbon dioxide absorption. Hypothermia was achieved by means of surface cooling through immersion in a tub of ice water, using $12 \mathrm{mg}$ of d-tubocurarine chloride intravenously to combat shivering. Rectal temperature was monitored every five minutes. After 75 minutes cooling, the temperature reached $26.5^{\circ} \mathrm{c}$ and remained there for some three hours. The course of anaesthesia is illustrated in Figure 1. Total anaesthetic time from intubation to extubation was eight hours. Respiration was assisted manually throughout the procedure. Blood pressure measured by cuff ranged from $140-100 \mathrm{~mm} \mathrm{Hg}$ systolic over $80-50 \mathrm{~mm} \mathrm{Hg}$ diastolic during cooling. A total of 2.5 $\mathrm{ml}$ per $\mathrm{kg}$ body weight of ether was used.

A right frontal craniotomy revealed a large arteriovenous malformation in the fronto-temporal lobe. Total removal was impossible and a silver clip was applied to the feeding vessel, which arose from the right anterior cerebral artery. The total blood loss of $600 \mathrm{mI}$ was replaced by transfusion of $600 \mathrm{ml}$ of bank blood together with $500 \mathrm{ml}$ of gelatine and $500 \mathrm{ml}$ of lactated Ringer's solution. No abnormality was detected on ECc tracing during anaesthesia. Frequent blood gas analyses were 
TABLE I

Arterial Blood Gas Analyses

\begin{tabular}{|c|c|c|c|c|c|c|}
\hline & 11:00am & $\begin{array}{l}10 \mathrm{~min} \\
\text { before cooling } \\
12: 00 \mathrm{pm}\end{array}$ & $1: 30 \mathrm{pm}$ & $3: 20 \mathrm{pm}$ & $5: 00 \mathrm{pm}$ & 7:00pm \\
\hline $\begin{array}{l}\text { Rect. temp. }\left({ }^{\circ} \mathrm{C}\right) \\
\mathrm{BP}^{\mathrm{BP} m \mathrm{Hg}} \\
\mathrm{PO}_{2} \mathrm{mmH} \\
\mathrm{PcO}_{2} \mathrm{mmHg} \\
\mathrm{pH} \\
\mathrm{BE}\end{array}$ & $\begin{array}{c}37.0 \\
126 / 60 \\
90 \\
46.2 \\
7.39 \\
-1.8\end{array}$ & $\begin{array}{c}36.5 \\
136 / 78 \\
240 \\
40.1 \\
7.38 \\
-1.3\end{array}$ & $\begin{array}{c}27.8 \\
116 / 76 \\
450 \\
44.6 \\
7.32 \\
-3.2\end{array}$ & $\begin{array}{c}26.6 \\
100 / 60 \\
400 \\
49.0 \\
7.24 \\
-7.8\end{array}$ & $\begin{array}{c}27.9 \\
118 / 70 \\
320 \\
39.6 \\
7.34 \\
-4.2\end{array}$ & $\begin{array}{c}32.8 \\
138 / 78 \\
240 \\
39.0 \\
7.32 \\
-5.2\end{array}$ \\
\hline
\end{tabular}

made from femoral arterial blood and they revealed a slight metabolic acidosis as shown in Table I. Intermittent intravenous administrations of sodium bicarbonate were intended to improve this acidosis.

Hydrocortisone in doses of $200 \mathrm{mgm}$ each was administered intravenously on the first and second post-operative day and an ampoule of Lutes depot was given again intrainuscularly on the first post-operative day. The post-operative course was uneventful and she was discharged on the 46 th post-operative day.

She was admitted again to the obstetric division of the hospital in labour in the early morning of April 26, 1970. A healthy girl weighing $3500 \mathrm{~g}$ was delivered by emergency Caesarean section performed under lumbar epidural anaesthesia using $260 \mathrm{mg}$ of 2.0 per cent lidocaine. Mother and child have done well to date.

\section{Incidence and Mortality}

\section{Disctission}

Although there are several studies ${ }^{i-0}$ to show that both the incidence and mortality of ruptured cerebral aneurysm or arteriovenous malformation are no higher in pregnant patients than in the population at large, subarachnoid haemorrhage due to either of these causes carries a high mortality.

Locksoley ${ }^{10}$ reported that 24 per cent of his patients suffering from a ruptured arteriovenous malformation died within the first 24 hours, 27 per cent within the first 48 hours, and 42 per cent within the first week. According to Poppen et al., ${ }^{11}$ about forty-two per cent of ruptured intracranial aneurysms terminated fatally. Pedowitz et al ${ }^{8}$ reported twenty deaths out of thirty-two cases of proven cerebral aneurysm during pregnancy, and Pool ${ }^{12}$ reviewing the literature, reported eight deaths among eleven gravid patients who suffered from ruptured cerebral aneurysm but who were not treated surgically.

\section{Review of the Literature}

Wilson et al. ${ }^{13}$ reported the case of a 31-year-old woman, 32 weeks pregnant, who suffered from an intracranial haemorrhage due to a ruptured aneurysm. The operation was carried out under ether-nitrous oxide-oxygen anaesthesia employing hypothermia to $30^{\circ} \mathrm{C}$ oesophageal. The operation was uneventful and she was delivered of a healthy female infant 31 hours after the craniotomy.

In 1962 Jensen ${ }^{14}$ presented the case of a 23 -year-old woman with intracranial aneurysm who was treated successfully by operation under hypothermia of 29 $30^{\circ} \mathrm{C}$ and was delivered of a healthy child at term. Boatman and associates ${ }^{15}$ re- 
moved an internal carotid artery aneurysm in the neck during pregnancy under hypothermia.

Pevehouse and Boldrey ${ }^{16}$ succeeded in the surgical treatment of an arteriovenous malformation under hypothermia in a 17-year-old pregnant woman. This was the first case of an arteriovenous anomaly treated surgically under hypothermia.

Two years later, in 1962, Boba ${ }^{17}$ reported two further operations for intracranial arteriovenous anomaly under hypothermia. The first was 20 years old, eight weeks pregnant and the major feeding vessels were occluded during uneventful moderate hypothermia. She was discharged during the fourteenth week of gestation. She passed a large amount of blood and clot per vagina immediately after discharge. The second was a 28-year-old woman in the 5th month of pregnancy and comatose for 3 days. After diagnostic angiography which revealed an arteriovenous anomaly of the right temporal lobe, an emergency excision was done under hypothermia, the lowest oesophageal temperature reached being $26.6^{\circ} \mathrm{C}$. Both the procedure itself and recovery were uneventful. She was discharged on the eleventh postoperative day and about four weeks later she delivered a macerated, premature stillborn. In both cases anaesthesia was maintained with ether and respiration was neither assisted nor controlled. Boba attributed the failure to carry their pregnancies to term to the early stage of gestation in the first case and to marked acidosis with undetected hypoxia in the second.

In commenting on Boba's paper, Virtue ${ }^{18}$ reported his experiences with hypothermia in several pregnant patients in various stages of gestation who had cardiac or intracranial operations with satisfactory results.

Burstein et al $^{\mathrm{Ig}}$ presented a successful repair for a ruptured berry aneurysm during gestation under hypothermia. The foetal electrocardiogram was monitored during the procedure and this revealed no foetal cardiac abnormality.

$\mathrm{Pool}^{12}$ reported 37 patients suffering from subarachnoid haemorrhage caused by verified intracranial aneurysms ruptured during pregnancy both from his own experiences and from the literature including reports by Wilson ${ }^{13}$ and Jensen. ${ }^{14}$ Eleven of these 37 patients were treated by bed rest only, with restricted ambulatory activity during gestation. There were eight maternal and five foetal deaths. Six patients were treated by cervical carotid occlusion with only one foetal death. Twenty patients were treated by intracranial operation during gestation. Hypothermia was utilized during twelve craniotomies followed by only one maternal death. The remaining eight patients were treated surgically without the use of hypothermia and in this series there was one maternal and one foetal death. Pool stressed the effectiveness of surgical treatment for ruptured intracranial aneurysm during pregnancy and that recurrent haemorrhage might occur if surgical treatment was not undertaken.

In 1965, Kamrin and his colleagues ${ }^{20}$ reported two successful intracranial operations under $\mathrm{N}_{2} \mathrm{O}$-oxygen-d-tubocurarine anaesthesia and hypothermia. They concluded that pregnancy was not to be a contraindication to the use of hypothermia.

Two years later, Dunn et al ${ }^{22}$ reported a case of arteriovenous malformation treated surgically under moderate hypothermia, However, no details of anaesthesia are given in his report.

Hehre ${ }^{2 .}$ reviewed twelve articles and concluded that carefully controlled hypothermia can be a life-saving procedure. Surgical intervention resulted in one ma- 
ternal and two foetal deaths. The time of gestation at which the operation took place or when subarachnoid haemorrhage occurred ranged from the eighth to the thirty-fourth week. Fourteen of the twenty cases were aneurysms, five were arteriovenous malformations, and one was a meningioma.

\section{Premedication}

Premedication has been discussed in only three instances. Jensen used $50 \mathrm{mg}$ of chlorpromazine intramuscularly I hour prior to anaesthesia. Kamrin ${ }^{20}$ gave his patients $200 \mathrm{mg}$ of secobarbital, $75 \mathrm{mg}$ of meperidine and $0.6 \mathrm{mg}$ of atropine intramuscularly 7 hours before the operation.

The authors administered $50 \mathrm{mg}$ of hydroxydione and $0.5 \mathrm{mg}$ of atropine to their patient $l$ hour before induction of anaesthesia with satisfactory results.

No descriptions of premedication were found anong the other reports. Generally, no premedication or light premedication is given to the gravid patient, and heavy premedication should be avoided because it tends to cause depression and prolonged recovery from anaesthesia. ${ }^{22}$

The authors administered "Lutes depot," containing $10 \mathrm{mg}$ of oestradiol benzoate and $125 \mathrm{mg}$ of hydroxyprogesterone caproate on the night before operation for its pregnancy stabilizing effect. Sex hormone was not used before anaesthesia in any other cases. It seems logical to administer these hormones during the first two trimesters of pregnancy to assure continuation of pregnancy in surgical patients who are likely to abort spontaneously. ${ }^{24}$ Boba's first case might have continued her pregnancy, if hormonal treatment had been given.

\section{Degree of Hypothermia}

The lowest rectal or oesophageal temperatures ranged from $26.5^{\circ} \mathrm{C}$ (Marsuki) to $32^{\circ} \mathrm{C}$ (Dunn). The low body temperature does not seem to have been responsible directly for the foetal deaths in Boba's cases. ${ }^{25}$ Hypothermia has been used for non-surgical patients during pregnancy. Rowbotham et al. ${ }^{26}$ utilized it successfully in a pregnant woman with a serious head injury. Her body temperature was maintained between $30^{\circ} \mathrm{C}$ and $36^{\circ} \mathrm{C}$ for seven days without complications.

Barter et al. ${ }^{2 i}$ applied hypothermia successfully to the treatment of fulminant toxaemia of pregnancy.

The depth of hypothermia depends on the duration and on the magnitude of the intracranial surgical intervention. In general, light or moderate hypothermia is to be selected for intracranial operation during pregnancy. Deep hypothernia is to be avoided since it may lead to hypotension, hypoxia ${ }^{28.20}$ and metabolic acidosis which in turn may cause spontaneous abortion. ${ }^{30}$ The use of hypothermia must be reserved for anaesthetists who have had considerable experience with it.

\section{Anaesthetic Agents}

The anaesthetic agents used are mentioned in seven of twenty cases. Four anaesthetics were with ether or ether-Nitrous Oxide, two with Nitrous Oxide-Oxygen and one with halothane-Nitrous Oxide. The authors employed cther because hypothermia below $30^{\circ} \mathrm{C}$ is easily achieved with deep anaesthesia and has the lowest incidence of ventricular fibrillation as compared to other anaesthetics such as halothane, methoxyflurane and thiopentone. ${ }^{31}$ At present we use neuroleptanaes- 
thesia (Droperidol and pentazocine) or methoxyllurane for light hypothermia by means of surface cooling, and employ ether anaesthesia for moderate and deep hypothermia,

\section{Metabolic acidosis and the use of $\alpha$-blockers}

A mild metabolic acidosis was observed in our case, which was attributable to deep ether anaesthesia and some interference with peripheral circulation. This was overcome by the intravenous administration of sodium bicarbonate intermittently, but more should have been given to correct the acidosis. Jensen ${ }^{14}$ administered $50 \mathrm{mg}$ of chlorpromazine intramuscularly prior to the induction of anaesthesia, and Kamrin et al, used $12.5 \mathrm{mg}$ of chlorpromazine during the initial cooling. The drug was given to reduce shivering and to improve peripheral circulation. We did not use it, since this was our first experience of hypothermia for a pregnant woman. As chlorpromazine is likely to produce sinus tachycardia, the authors employed triflupromazine in doses of $0.25-0.5 \mathrm{mg}$ per $\mathrm{kg}$ body weight before and during cooling. This drug produces no tachycardia and vasodilation and is not contraindicated in pregnant patients.

\section{Hypotension}

Several authors ${ }^{13.14,16,26}$ employed induced hypotension in combination with hypothermia. Extreme hypotension produces tissue hypoxia even in the presence of hypothermia. In gravid women, hypotension and hypoxia may be conducive to abortion. ${ }^{28-30}$ Pevehouse ${ }^{18}$ experienced a foetal death in connection with an operation for meningioma in a 17-year-old woman in the 34th week of gestation. In this case hypotension without hypothermia was utilized and systolic blood pressure was maintained below $80 \mathrm{mn} \mathrm{Hg}$.

\section{Use of Osmotic Diuretics}

Osmotic diuretics such as mannitol and urea produce a slack brain which greatly facilitates intracranial operations. Several workers, ${ }^{32,38}$ however, have shown that mannitol crosses the placenta and increases the osmolarity of the foetal plasma which in turn is followed by dehydration. Wakusawa et al. ${ }^{\mathbf{3 4}}$ reported a cardiac arrest during hypothermia associated with the intravenous infusion of osmotic diuretics. This implies to us that the administration of osmotic diuretics for gravid patients is contraindicated. ${ }^{6}$

\section{Management of Delivery}

Our patient delivered a healthy female girl by emergency Caesarean Section without any complications. The same management was employed in three other cases (Scoville, Pool) while nine others were by the vaginal route, and five by forceps.

Several uneventful vaginal deliveries have been reported in women with proven aneurysms ${ }^{95,88}$ and it is a general consensus that the stress of labour does not precipitate the rupture of an aneurysm. ${ }^{87}$ However, there is no effective means of knowing when rupture will occur, and if rupture occurs, it carries a high incidence of fatality as shown in the report by Pool, ${ }^{10}$

A full term vaginal delivery is allowed under general or regional anaesthesia if 
the aneurysm has been successfully obliterated. But if it has been treated conservatively by muscle wrapping, plastic coating or carotid occlusion or, if an arteriovenous malformation has been clipped, low forceps delivery or a Caesarean Section under regional block or general anaesthesia is preferred to avoid the strain of labour.

\section{Monitoring}

Monitoring of maternal ECC and EEG, direct measurement of radial or brachial arterial pressure and of central venous pressure and frequent gas analyses of arterial blood greatly facilitate the anaesthetic management. Barter et al., ${ }^{37}$ Hess and Davis ${ }^{\mathrm{Bz}}$ also recommend monitoring of the foetal electrocardiogram.

\section{SUMmanY AND CONCLUSIONS}

The case of a 20 -year-old pregnant patient who underwent a craniotomy under hypothermia is presented. She was four months pregnant and suffered from a subarachnoid haemorrhage. Hypothermia is viewed as a safe procedure for this kind of situation, conducive of high foetal and maternal survival rates. It is stressed that severe acidosis and hypoxia during hypothermia may be the cause of a high incidence of spontaneous abortion. The technique must be reserved for anaesthetists who have considerable experience with hypothermia and its application.

\section{RÉSUMÉ}

Nous présentons le cas d'une malade de 20 ans, enceinte, qui a subi une craniotomie sous hypothermie. Alors qu'elle était enceinte de quatre mois, elle a fait une hémorragie sous arachnoldienne. Nous considérons I'hypothermie comme une technique offrant de la sécurité pour de semblables malades; elle est suivie d"un taux élevé de survivance foetale et matemelle. La cause d'un taux b́levé d'avortement spontané pourrait être lacidose marquée et l'hypoxie au cours de l'hypothermie. Cette technique devrait être employée de préférence par des anesthésistes possédant une grande expérience dans lemploi de l'hypothermie et connaissant ses conséquences.

\section{REFERENCES}

1. Mckissor, W.; PaINe, K.W.E; \& Walsh, L.S. The Value of Hypothermia in the Surgical Treatrient of Ruptured Intracranial Aneurysms, J. Neurosurg., I7: 700 (1960).

2. Hale, D.E.; Collis, J.S. Jn.; \&C KING, M.H. Intracranial Aneurysmal Surgery with and without Hypothermia, Surgery, 32: 338 (1962).

3. PAU, , R.L. \& ARnold, J.G. Operative Factors Influencing Mortality in Intracrarial Aneurysm Surgery: Analysis of 186 Consecttive Cases; J. Neurosurg., 32: 289 (1970).

4. Hunter, A.h. Neurosurgical Anaesthesia, Oxford, Blackwell, 1964.

5. Bopa, A. Hypothermia for the neurosurgical patients Springfield, Ill. Charles, C. Thomas (1960).

6. HzWER, A.J.H. Intravenous Anesthesia, Hypothermia, International Anesthesiology Clinics, Vol. 2, No. 4, Little Brown, 1964.

7. BrYans, F.E. Vascular Accidents in Maternal Mortality, Clin. Obstet. Gynec., 6: 861 (1963).

8. Pepowitz, P.; Perrel.., A.; \& Brooxc Yn, N.Y. Aneurysms Complicated by Pregnancy, Part II Aneurysms of the Cerebral Vessels, Amer. J. Obst. Gynec, 73: 736 (1957). 
9. Decker, A. \& Rowe, E.C. Subarachnoid Hemorrhage Complicating Pregnancy, Amer. J. Surg, $85 ; 561$ (1953).

10. LocksoleY, H.B. Natural History of Subarachnoid Hemorrhage, Intracranial Aneurysms and Arteriovenous Malformations. 25: 321 (1966)

11. Pooppes, J.L. \& FAGER, C.A. Intracranial Aneurysms: Results of Surgical Treatment, J Neurosurg, 17: 283 (1960).

12. Pool, J.L. Treatment of Intracranial Aneurysms during Pregnancy, JAMA, 192: 109 (1965).

13. WILson, F. \& SEDzimIr, C.B. Hypothermia and Hypotension during Craniotomy in a Pregnant Woman, Lancet, 2: 947 (1959).

14. Jensen, F. Hypothermia and Controlled Hypotension Employed in An Operation during Pregnancy, Danish Medical Bulletin, 9: 250 (1962).

15. Boaman, K.K. \& Eramporf, V.A. Excisjon of an Internal Carotid Aneurysm during Pregnancy Employing Hypothermia and a Vascular Shunt, Ann. Surg., I48: 271 (1958).

18. PEvarouse, B.C. \& Boldaey, E, Hypothermia and Hypotension for Intracranial Surgery during Pregnancy, Amer. J. Surg., $100: 633$ (1960).

17. BoвA, A. Hypothermia, Appraisal of Risk in 110 Consecutive Patients, ]. Neurosurg. 19: 924 ( 1962 ).

18. VIatuE, R.W. Comment in Survey of Anesthesiology, 8: 133 (1964).

19. Bunsterw, P.N,; Perese, D.M.; \& KaMiNsK, C.J. Puptured Berry Aneurysm during Pregnancy, Successful Repair under Hypothermia, Obstet. Gynece, 24: 463 (1964).

20. Kamerni, R.P. \& MASLAND, W. Intracranial Surgery under Hypothermia during Pregnancy, Arch Neurol., 13:70 (1965).

21. HeIfFE, F.W. Hypothermia for Operations during Pregnancy, Anesth. \& Analg, 44: 424 \{1965).

22. Duns, J.M. \& Faskind, R. Rupturc of a Cerebral Arteriovenous Malformation during Preguancy, Obstet. Gynec., 30: 423 (1967).

23. Bonica, J.J. Principles and Practice of Obstetric Analgesia and Anesthesia, Philadelphia, F.A. Davis, 1969 (See Vol. 2, p. 1097 )

24. WiLLinMs, R.H. (editor). Textbook of Endocrinology, Asian Edition, Tokyo, Hakko Comp. 1966, p. 458 ,

25. LECrx, M. The Effect of Hypothermia Applied in the given Stages of Pregnancy on the Number and Form of Vertebrae in the Offspring of White Mice, Experientia, 21: 452 (1985).

28. Rowbotham, G.F.; Beul, K.; Akenhead, J.; \& CaIrNs, A. A Serious Head Injury in a Pregnant Women Treated by Hypothermia, Lancet, 2: 1016 (1957).

27, BARTER, R.H.; ALBERT, S.M.; \& WINSHEL, $A . W$. The Use of Hypothermic Hypotensive Technique in Fulminant Toxemia of Pregnancy. Amer. J. Obst. Gynec. 76: 1062 (1958)

28. Wookey, C.F.; Runco, V.; Levin, H.S.; \& Ryan, J.M. Pregrincy and Congenital Heart Disease, Circulation, $24: 1075$ (1961).

29. Copeland, W.E.; Woolex, C.F.; RYan, J.M.; Hunco, V.; \& Levin, H.S. Pregnancy and Congenital Heart Disease. Amer, J. Obst. Gynec., 86: 107 (1063).

30. Lrtruer, W.A. Successful Pregnancy in a Patient with Ebstein's Anomaly. Brit. Heart. J. 32: $711(1970)$.

31. YonezawA, T. Klinlsche Anwendung der Teefen Hypothermic auf der Cebiet der Interkardialen Chirurgie, Anaesthetist, 11: 349 (1962).

32. Bruns, D.D.; LindFr, R.O.; Dhose, F.E.; \& Battaglia, F. The Placentral Transfer of Water from the Fetus to the Mother Following the Intravenuus Infusion of Hypertonic Mannitol to the Maternal Rabbit, Amer. J. Obst. Gynec, $86: 60$ (1963).

33. Batraglia, F.: Prystowsky, H.; Smisson, C.; Helleceras, A; \& Brons, P.D. Effect of the Administration of Fluids Intravenously to Mothers upon the Concentration of Water and Elextrolytes in Plasma of Human Fetus. J. Pediat., 25: 2 (1960).

34. Waxusawa, R. A Cardiac Arrest Following Hypertonic Solution Injection under Hypothermia. Jap. J. Anes., 18: 759 (1969).

35. CAyner, D.E. Subarachnold hemorrhage in pregnancy. Proc. Hoy. Soc. Med., 52: 950 (1959).

36. Feldman, R.L.; Gross, S.W.; Wimprinejmer, S. Ruptured Intracranial Aneurysm During Pregnancy: Diagnosis and Treatment. Amer. J. Obst. Cynec., 70: 289 (1955).

37. Bonrcs, J.J. Principles and Practice of Obstetric Analgesia and Anesthesia, Philadelphia, F.A. Davis, Vol. 2, (See page 1055), 1969.

38. Hess, O.W. \& DAvis, C.D. Electronic Evaluation of the Fetal and Maternal Hate During Hypothermia ia a Pregnant Woman, Amez. J. Obst. Gynec., $89: 801$ (1964). 